\title{
Reference values for respiratory muscle strength in brazilian children: a review
}

\author{
Camila Isabel Santos Schivinski ${ }^{1}$, Renata Maba Gonçalves² ${ }^{2}$ Tayná Castilho $^{3}$
}

DOI: http://dx.doi.org/10.7322/jhgd.122912

\begin{abstract}
:
Introduction: Reference values and equations show strong variability and regional differences, despite a well-established role of the assessment of respiratory muscle strength (RMS) in children, with the objective to follow up on diseases that affect the function of respiratory muscles and enable adequate growth and development.
\end{abstract}

Objective: To describe reference values and prediction equations of maximal respiratory pressures for Brazilian children.

Methods: Literature review was conducted using databases LILACS, MEDLINE and Science Direct, and descriptors established by DeCS of the Virtual Health Library: reference values, child, respiratory muscle strength, predictive equations and their respective synonyms in English.

Results: Six clinical trials were carried out, which determined reference values for children in various Brazilian regions. There was a relationship among RMS values and other factors, such as age, height and body mass. However, there was a significant difference among the data in the Brazilian states and divergence among the predicted values.

Conclusion: There is a consensus on the relationship among RMS, anthropometric factors and regional influences. The articles studied reported diverging predicted values and reference equations.

Keywords: Reference Values. Child. Respiratory Muscle Strength. Predictive Equations.

\section{INTRODUCTION}

The assessment and monitoring of respiratory function in children have experienced considerable progress in the last 30 years. Technological advancements, reliable studies and clinical applications have strongly contributed to health care management in this age group ${ }^{1,2}$. Some of the most commonly analyzed parameters for respiratory function include maximal respiratory pressures (MRP), which became synonymous with respiratory muscle strength $^{3}$. MRP can be assessed by measuring their inspiratory (Maximum Inspiratory Pressure - MIP) and expiratory (Maximal Expiratory Pressure - MEP) components, using specific tools, such as a manovacuometer ${ }^{4,5}$.

These measurements are useful in clinical practice because they are simple and non-invasive. But, they re- quire collaboration among individuals being examined, which may underestimate the results, even in the absence of muscle weakness ${ }^{6}$. This procedure is even more sensitive when evaluating smaller children ${ }^{7}$. It is now well established that some factors may influence MRP, such as age, sex, smoking, physical activity and anthropometric factors ${ }^{8,9,6,7,10}$. Some studies also suggest that ethnicity may influence MRP values. In a multidisciplinary study involving Malayan, Chinese and Indian adults, significant ethnic differences were found in $\mathrm{MRP}^{11}$. Brazilian studies also point in this direction, considering the territorial dimensions and ethnic diversity in Brazil ${ }^{12,13,14}$.

Specifically for the pediatric population, higher MRP were observed with increasing age, as well as a positive correlation with weight and height ${ }^{11,15,16,17,18,19}$. To date, the most referenced data on MRP reference values

1 Ph.D. in Children and Adolescent Heath from the Medical School of UNICAMP; Professor of the Undergraduate and Graduate Programs at UDESC.

2 Master's Degree in Physiotherapy from Santa Catarina State University - UDESC.

3. Graduate student in Physiotherapy at Santa Catarina State University - UDESC

Corresponding author: Camila I Santos Schivinski - e-Mail: cacaiss@yahoo.co80

Suggested Citation: Schivinski CIS, Gonçalves RM, Castilho T. Reference values for respiratory muscle strength in brazilian children: a review. J Hum Growth Dev. 2016; 26(3): 374-379. DOI: http://dx.doi.org/10.7322/jhgd.122912

Manuscript submitted: 18 May 2016, accepted for publication 26 Jun 2016. 
for healthy children can be found in the studies conducted by Gaultier and Zinman ${ }^{19}$, Wilson et al. ${ }^{18}$, Szeinberg et al. ${ }^{15}$, Tomalak ${ }^{20}$ and Domènech-clar et al. ${ }^{17}$, with great variability in the values observed. Nevertheless, some authors ${ }^{21,22}$ used predicted equations for adults, such as those proposed by Black and Hyatt ${ }^{23}$ and Neder et al. ${ }^{12}$, in the discussion of their studies involving pediatric patients. The clinical applicability of the equations for MRP assessment in children can be mainly observed by monitoring chronic diseases, such as neuromuscular diseases, asthma and cystic fibrosis. However, there are no reference values widely accepted for Brazilian children. There are few published data on the subject in Brazil, and most of them are quite recent. Schmidt et al. ${ }^{24}$, Barreto ${ }^{25}$ and HeinzmannFilho et al. ${ }^{26}$ proposed reference values and prediction equations for this age group, and Nascimento et al. ${ }^{27}$ and Barreto $^{25}$ verified the applicability of foreign equations to their samples of children.

Given the above, the identification and establishment of MRP reference values for Brazilian healthy children may contribute to better understand the muscle and ventilatory dynamics of this population, as well as provide comparative studies with improved methodological quality and increased reliability for the clinical follow-up of this age group. However, several studies in different populations show no consensus on MRP reference values and on the variables that correlate with their respective values in the equations, which may indicate that regional differences have a strong influence in these results.

Thus, this study aimed to describe reference values and prediction equations of maximal respiratory pressures for Brazilian children.

\section{METHODS}

The literature review strategy included electronic searching using three bibliographic online databases: LILACS (Latin American and Caribbean Information in Health Sciences), MEDLINE (Medical Literature Analysis and Retrieval System Online) and Science Direct. Consultations on online databases were conducted from February to October 2015. From a preliminary analysis, the subject-related descriptors established by DeCS (Health Sciences Descriptors) of the Virtual Health Library were identified, namely, reference values, child, respiratory muscle strength, predictive equations, and their synonyms in English.

The following criteria were used to include the articles in this review: (1) indexed in specialized journals, (2) published after 1980, and (3) related to the presentation of MRP reference values and prediction equations for Brazilian children. Book chapters, theses, dissertations were excluded, as well as literature that was not published in either Portuguese or English.

The following data was extracted from the selected articles and entered into an Excel spreadsheet (Microsoft Office, 2010): title, authors, year and scientific journal. This procedure was used to identify all duplicate references and facilitate the selection process. This process involved two reviewers blinded to the subject, who deter- mined whether the articles satisfied all previously established inclusion criteria. First, the reviewers read the titles and then the abstracts. The articles were reviewed in full if they did not provide enough information to be excluded from this preliminary analysis. Compatible publications were listed for further review.

\section{RESULTS}

In total, the research identified 18 articles in the consulted databases. The diagram (Figure 1) shows that 12 articles were excluded by a sequential process, as they did not meet the established inclusion criteria. At the end of the investigation, only six clinical trials met all of the criteria, and were included in the selection.

Based on the analysis of the selected publications, Table 1 provides information on the characteristics of each included research: year, authors, method, sample size and age group, as well as maximal inspiratory and expiratory pressures. Predictive equations for MRP proposed in these studies are shown in Table 2.

A relationship among MRP values and factors, such as age, height and body mass could be observed, as well as relevant differences among the data in the analyzed Brazilian states. So far, discrepancies among the obtained predicted values have been observed using the proposed reference equations.

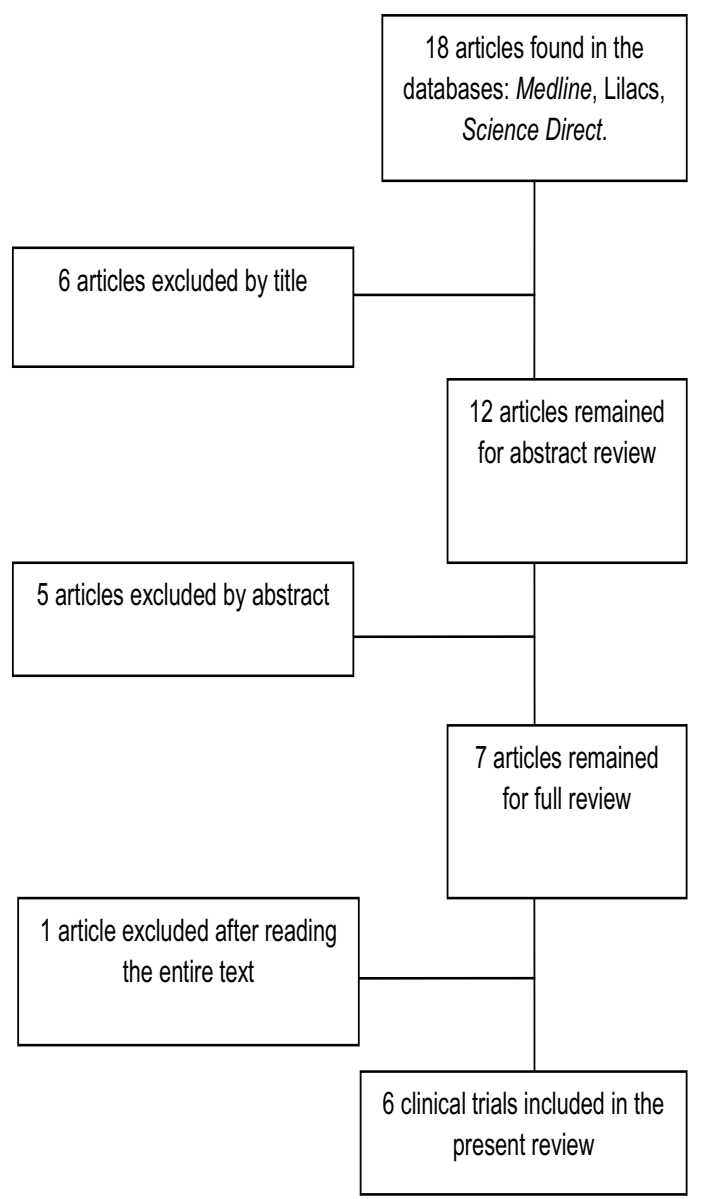

Annex

Figure 1: Diagram showing selection and inclusion processes of the studies. 


\section{DISCUSSION}

Analysis of reference values and prediction equations for MRP in the Brazilian population was first conducted in adults in $1985^{28}$. Next, other researchers conducted studies with the same objective; however, they identified significant discrepancies among the results obtained in the different Brazilian states ${ }^{12,14}$. Likewise, re- searches on MRP have also been conducted in children. In this population, studies have focused on predicting normal values for each age group, as well as on monitoring several diseases that may either directly or indirectly affect respiratory muscle function. There are few studies with Brazilian children in the literature, as shown in Tables 1 and 2, although its clinical applicability and relation with anthropometric adequacy are well established ${ }^{26}$. Equations

Table 1: Brazilian studies on reference values for MRP in children

\begin{tabular}{|c|c|c|c|c|c|c|c|c|}
\hline \multirow[b]{2}{*}{ Study } & \multirow[b]{2}{*}{ State } & \multirow[b]{2}{*}{$\mathbf{N}$} & \multirow[b]{2}{*}{ Age } & \multirow[b]{2}{*}{ Group } & \multicolumn{3}{|c|}{ Reference Values Found } & \multirow[b]{2}{*}{$\begin{array}{c}\text { MEP } \\
F\end{array}$} \\
\hline & & & & & $\begin{array}{c}\text { Group } \\
\mathbf{M}\end{array}$ & $\begin{array}{c}\text { MIP } \\
\text { M }\end{array}$ & $\begin{array}{c}\text { M } \\
\text { F }\end{array}$ & \\
\hline \multirow[t]{5}{*}{ Schmidt et al. (1999) } & RS & 672 & $6-14$ & 6 & 83 & 72 & 62 & 62 \\
\hline & & & & 7 & 71 & 74 & 61 & 63 \\
\hline & & & & 8 & 82 & 71 & 69 & 67 \\
\hline & & & & 9 & 85 & 82 & 70 & 66 \\
\hline & & & & 10 & 82 & 82 & 69 & 74 \\
\hline Nascimento et al. (2012) & RN & 40 & $7-10$ & - & 70.55 & 77.40 & 61.50 & 77.40 \\
\hline Barreto (2012) & MG & 90 & $6-12$ & - & 80.65 & 84.35 & 76.14 & 74.55 \\
\hline \multirow[t]{3}{*}{ Heinzmann-Filho et al. (2012) } & RS & 171 & $4-12$ & $4-6$ & 73.5 & 85.67 & 60.62 & 71.54 \\
\hline & & & & $7-9$ & 89.73 & 104.4 & $80-83$ & 87.83 \\
\hline & & & & 10.12 & 104.12 & 119.96 & 94.94 & 112.18 \\
\hline \multirow[t]{6}{*}{ Gomes et al. (2014) } & $\mathrm{SP}$ & 148 & $5-10$ & 5 & 46.36 & 42.10 & 43.68 & 56.36 \\
\hline & & & & 6 & 63.33 & 51.81 & 47.27 & 55 \\
\hline & & & & 7 & 65.00 & 56.15 & 68.46 & 65.00 \\
\hline & & & & 8 & 64.5 & 61.66 & 66.11 & 70.5 \\
\hline & & & & 9 & 88.33 & 68.12 & 67.5 & 90 \\
\hline & & & & 10 & 80.66 & 65.00 & 67.5 & 79.33 \\
\hline \multirow[t]{2}{*}{ Borja et al. (2015) } & $\mathrm{RN}$ & 144 & $7-11$ & $7-8$ & 45.42 & 57.63 & 30.02 & 41.13 \\
\hline & & & & $9-11$ & 52.72 & 67.13 & 37.32 & 50.63 \\
\hline
\end{tabular}

Source: Table produced by the authors based on reference studies. Legend: RS: Rio Grande do Sul; RN: Rio Grande do Norte; MG: Minas Gerais; SP: São Paulo; N: sample size; MIP: maximal inspiratory pressure (cmH2O); MEP: maximal expiratory pressure (cmH2O); M: males; F: females.

Table 2: Predictive equations for MRP proposed by Brazilian studies

\begin{tabular}{|c|c|c|c|c|c|}
\hline & $\begin{array}{l}\text { Schmidt et al. } \\
\text { (1999) }\end{array}$ & $\begin{array}{l}\text { Barreto } \\
\text { (2012) }\end{array}$ & $\begin{array}{l}\text { Heinzmann-Filho } \\
\text { et al. (2012) }\end{array}$ & $\begin{array}{l}\text { Gomes et al. } \\
(2014)\end{array}$ & $\begin{array}{l}\text { Borja et al. } \\
(2015)\end{array}$ \\
\hline \multicolumn{6}{|l|}{ Boys } \\
\hline MIP & $\begin{array}{c}-324.296+(-21.833 \cdot A) \\
+(-0.122 \cdot H)\end{array}$ & $\begin{array}{c}21.46+(14.3 \cdot F V C) \\
(1.65 \bullet T C)+(2.54 \cdot T S)\end{array}$ & $\begin{array}{l}17.879-(0.674 \cdot H) \\
\quad-(0.604 \bullet W)\end{array}$ & $\begin{array}{c}-62.2+1.26 \cdot A+ \\
0.50 \cdot B M+80.1 \cdot H\end{array}$ & $\begin{array}{c}62.1+15.4 \bullet(\operatorname{sex}=1) \\
+7.3 \cdot \text { Age }\end{array}$ \\
\hline MEP & $\begin{array}{c}-188.261+(-9.698 \cdot A) \\
+(-0.122 \bullet H)\end{array}$ & $\begin{array}{l}60.5+\left(13.2 \cdot \mathrm{FEV}_{1}\right) \\
\quad-(9.17 \cdot \operatorname{sex}=0)\end{array}$ & $\begin{array}{c}47.417+(0.898 \cdot W) \\
+(3.166 \bullet A)\end{array}$ & $\begin{array}{c}49.6+7.23 \cdot A+0.47 \\
\cdot B M+(37.3 \cdot H)\end{array}$ & $\begin{array}{l}\text { 73.7+16.5•sex } \\
+9.5 \bullet \text { Age }\end{array}$ \\
\hline \multicolumn{6}{|l|}{ Girls } \\
\hline MIP & $\begin{array}{l}12.989+(1.059 \cdot A) \\
+(0.34 \cdot H)\end{array}$ & The same for boys. & $\begin{array}{l}14.226-(0.551 \cdot H) \\
-(0.638 \cdot W)\end{array}$ & $\begin{array}{c}7.31+3.2 \cdot A+0.47 \bullet \\
B M+9.7 \bullet H\end{array}$ & $\begin{array}{c}62.1+15.4 \cdot(\operatorname{sex}=0) \\
+7.3 \cdot \text { Age }\end{array}$ \\
\hline MEP & $\begin{array}{l}53.732+(3.702 \bullet A) \\
\quad+(4.368 \bullet H)\end{array}$ & $\begin{array}{c}60.5+(13.2 \cdot \text { FEV1 }) \\
-(9.17 \cdot \text { sex }=1)\end{array}$ & $\begin{array}{l}30.045+(0.749 \cdot W) \\
\quad+(4.213 \cdot A)\end{array}$ & $\begin{array}{c}-10.8+4.05 \cdot \mathrm{A} \\
+0.08 \cdot \mathrm{BM}+30.4 \cdot \mathrm{H}\end{array}$ & $\begin{array}{c}73.7+16.5 \bullet \text { sex9.5•Age } \\
+9.5 \bullet \text { Age }\end{array}$ \\
\hline
\end{tabular}

Source: Table produced by the authors based on reference studies. Legend: MIP: maximal inspiratory pressure (cmH2O); MEP: maximal expiratory pressure (cmH2O); A: age (years);

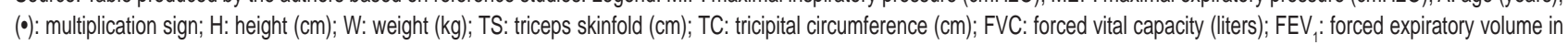
one second (liters); BM (body mass); Age: age group of 7 to 8 years $=0,9$ to 11 years $=1$.

and values for these measurements are often published in both national and international journals, considering factors such as age, sex, height and geographical area ${ }^{8,14}$ :

In children, it is particularly important to understand the evolution of respiratory muscle strength during clinical follow-ups and the child's development and growth, as MRP values increase with age ${ }^{9}$. Furthermore, there is a consensus on the clinical indication to moni- tor respiratory muscles in children with neuromuscular diseases, unexplained dyspnea or disproportionate to the amount of effort expended, corticosteroid-induced myopathy, as well as in chronic respiratory diseases that compromise the function of these muscles, such as cystic fibrosis and asthma $a^{5,7,29}$.

The first Brazilian study including children was developed by Schmidt et al. ${ }^{24}$ in the municipalities of Pan- 
ambi and Cruz Alta in the State of Rio Grande do Sul. It included 672 subjects and proposed reference values and predictive equations for MRP according to age and height. These were considered the best predictors for MRP, but the study also identified a correlation among MRP, weight and BM. To measure MIP and MEP, the children remained in a sitting position and used a nose clip during five tests. The study does not mention reproducibility and acceptability criteria.

Recently, Nascimento et al. ${ }^{27}$ have investigated the applicability of Wilson's ${ }^{18}$ equations in a sample of children of Rio Grande do Norte, aging between 7 and 10 years, as these are widely referred to in the medical literature and present reference values. They further compared these findings with those reported by Szeinberg et al. ${ }^{15}$ and Domènech-clar et al. ${ }^{17}$. 40 eutrophic children participated in the study (sample calculation is not reported), and each maneuver was performed three to seven times according to Black and Hyatt ${ }^{23}$. The greatest value was considered, in compliance with the acceptability and reproducibility criteria. MRP results similar to those reported by Domènech-clar et al. ${ }^{17}$ and lower than those found by Szeinberg et al. ${ }^{15}$ could be observed. The application of Wilson's ${ }^{18}$ equations enabled prediction of MRP values in the studied sample.

Wilson's ${ }^{18}$ equations were used in British adults and children, and their reference values for MIP are: $75 \mathrm{cmH} 2 \mathrm{O}$ in boys and $63 \mathrm{cmH} 2 \mathrm{O}$ in girls; MEP: $96 \mathrm{~cm}-$ $\mathrm{H} 2 \mathrm{O}$ and $80 \mathrm{cmH} 2 \mathrm{O}$ for boys and girls, respectively. The findings reported by Wilson ${ }^{18}$, associated with the MRP values proposed by Domenech-Clar ${ }^{17}$ for the Spanish population and the studies conducted by Szeinbert ${ }^{15}$, are the most widely used reference values in the literature.

In 2012, Barreto ${ }^{25}$ evaluated 90 healthy children of the State of Minas Gerais in order to propose a new prediction equation for MRP and verify the applicability of the equations proposed by Wilson ${ }^{18}$, Schmidt et al. ${ }^{24}$ and Domènech-clar et al. ${ }^{17}$ to their sample. They used the model developed by Black and Hyatt ${ }^{23}$ and the standards of the Brazilian Thoracic Society ${ }^{4}$ to conduct all assessments. To analyze the correlation among MRP and other variables, the following items were considered: height, weight, BMI, tricipital circumference, triceps skinfold, forced vital capacity (FVC) and forced expiratory volume in one second $\left(\mathrm{FEV}_{1}\right)$, age, sex, MIP and MEP. Spirometric data (FVC and $\mathrm{FEV}_{1}$ ) and triceps skinfold and tricipital circumference showed the best correlation with MRP. The equations proposed by Wilson ${ }^{18}$, Schmidt et al. ${ }^{24}$ and Domènech-Clar ${ }^{17}$ were unable to predict MRP values for the studied sample. The authors suggested regional studies to predict MRP in Brazil.

A study by Heinzmann-Filho et al. ${ }^{26}$ assessed 171 subjects of both sexes, and found a correlation among MRP, age, height, weight and FVC. For regression models, height and weight are best variables to predict MIP; whereas weight and age, to predict MEP. The authors concluded that the behavior of both pressures may be explained by age, height and weight.

One of the most recent studies was conducted by Gomes et al. ${ }^{30}$, which assessed 148 children, boys and girls, aged between five and 10 years. The study was conducted in the city of São Paulo. For both sexes, correlation was found among MRP, body mass, age and height. When comparing the values obtained with the equations proposed by Wilson ${ }^{18}$, there was no significant difference for MIP for both sexes and MEP for girls. However, significant differences could be observed when the values were compared with those predicted by Heinzmann-Filho et al. ${ }^{26}$.

Borja et al. ${ }^{31}$ has published the latest Brazilian study so far. It was carried out in the state of Rio Grande do Norte and included 144 children between seven and 11 years of age. The authors observed a correlation among MIP, sex, age and weight. In addition to these variables, MEP also showed significant correlation with height. However, with the regression analysis, only sex and age significantly contributed to MRP. These results were similar to those proposed by Domènech-clar et $\mathrm{al}^{17}$.

The development of predictive equations and reference values for MRP in this age group is still necessary, considering the Brazilian context and the importance of MRP values as clinical outcomes in health assessment and prognostic index for children's diseases. Nevertheless, given the methodological variability, the lack of consensus between reference values and predictive equations reported in the studied literature, it is essential that further studies be conducted with standard data collection methods and numerically consistent sampling, in order to obtain reliable results that may be used nationally and regionally.

The American Thoracic Society confirms this opinion in its review of 1991, i.e. the reference values should be regionalized to reflect their behavior in each popula$\operatorname{tion}^{32}$. Thus, the use of international equations or from several regions of Brazil - which has continental dimensions and great ethnic diversity- may not reflect the respiratory muscle function of the studied population, and lead to over- or underestimation of values.

\section{CONCLUSION}

The studies presented in this study agree that there is a significant relationship among MRP, age, height and body mass of children. However, there is wide divergence among the predicted values obtained using existing reference equations. It would be interesting to determine predicted values and reference equations according to each Brazilian region, as there seem to be regional differences in MRP, which should be further investigated. 


\section{REFERENCES}

1. Hammer J, Eber E. Progress in Respiratory Research: Pediatric Pulmonary Function Testing. Basel: Karger; 2005.

2. Fauroux $B$, Aubertin G. Measurement of maximal pressures and the sniff manoeuvre inchildren. Paediatr Respir Rev. 2007;8(1):90-3. DOI: http://dx.doi.org/10.1016/j.prrv.2007.02.006

3. Troosters T, Gosselink R, Decramer M. Respiratory muscle assessment. Eur Respir Mon.2005;31:57-71. DOI: http://dx.doi.org/10.1183/1025448x.00031004

4. Souza RB. Pressões respiratórias estáticas máximas. J Pneumol. 2002;28(3):155-165.

5. Ribeiro SNS, Fontes MJF, Duarte MA. Avaliação da força muscular respiratória e da função pulmonar por meio de exercício em crianças e adolescentes com asma: ensaio clínico controlado. Pediatria. 2010;32(2):98-105.

6. American Thoracic Society/European Respiratory Society. ATS/ERS Statement on Respiratory Muscle Testing. Am J Respir Crit Care Med. 2002;166(4);518-624. DOI: http://dx.doi.org/10.1164/rccm.166.4.518

7. Fauroux B, Lofaso F. Measurements of respiratory muscle function in children. Paediatr Pulmonary Function Testing Prog Respir Res. 2005;33:138-47. DOI: http://dx.doi.org/10.1159/000083531

8. Chen $\mathrm{HI}$, Kuo CS. Relationship between respiratory muscle function and age, sex, and other factors. J Appl Physiol (1985). 1989;66(2):943-48.

9. Harik-khan RI, Wise RA, Fozard JL. Determinants of maximal inspiratory pressure: The Baltimore longitudinal study of aging. Am J Respir Crit Care Med. 1998;158(5 Pt 1):1459-64. DOI: http://dx.doi.org/10.1164/ ajrccm.158.5.9712006

10. Evans JA, Whitelaw WA. The assessment of maximal respiratory mouth pressures in adults. Respir Care. 2009;54(10):1348-58.

11. Johan A, Chan CC, Chia HP, Chan OY, Wang YT. Maximal respiratory pressures in adult Chinese, Malays and Indians. Eur Respir J. 1997;10(12):2825-8. DOI: http://dx.doi.org/10.1183/09031936.97.10122825

12. Neder JA, Andreoni S, Lerario MC, Nery LE. Reference values for lung function tests. II. Maximal respiratory pressures and voluntary ventilation. Braz J Med Biol Res. 1999;32(6):719-27. DOI: http://dx.doi. org/10.1590/S0100-879X1999000600007

13. Parreira VF, França DC, Zampa CC, Fonseca MM, Tomich GM, Britto RR. Pressões respiratórias máximas: valores encontrados e preditos em indivíduos saudáveis. Rev Bras Fisioter. 2007;11(5):361-8. DOI: http://dx.doi.org/10.1590/S1413-35552007000500006

14. Costa D, Gonçalves HA, Lima LP, Ike D, Cancelliero KM, Montebelo MIL. Novos valores de referência para pressões respiratórias máximas na população brasileira. J Bras Pneumol. 2010;36(3):306-12. DOI: http:// dx.doi.org/10.1590/S1806-37132010000300007

15. Szeinberg A, Marcotte JE, Hoizin H, Mindorff C, England S, Tabachnik E, et al. Normal values of maximal inspiratory and expiratory pressures with a porTable apparatus in children, adolescents, and young adults. Pediatr Pulmonol. 1987;3(4):255-9. DOI: http://dx.doi.org/10.1002/ppul.1950030411

16. Choudouri D, Aithal M, Kuhlkarni VA. Maximal Expiratory Pressure in Residential and Non- Residential School Children. Indian J Pediatr. 2002;69(3):229-32.DOI: http://dx.doi.org/10.1007/BF02734229

17. Domènech-Clar R, López-Andreu JA, Compte-Torrero L, De Diego-Damiá A, Macián-Gisbert V, Perpiñá-Tordera $\mathrm{M}$, et al. Maximal static respiratory pressures in children and adolescents. Pediatr Pulmonol.2003;35(2):126-132. DOI: http://dx.doi.org/10.1002/ppul.10217

18. Wilson SH, Cooke NT, Edwards RH, Spiro SG. Predicted normal values for maximal respiratory pressures in caucasian adults and children. Thorax. 1984;39(7):535-8. DOI: http://dx.doi.org/10.1136/thx.39.7.535

19. Gaultier C, Zinman R. Maximal static pressures in healthy children. Respir Physiol.1983;51(1):45-61. DOI: http://dx.doi.org/10.1016/0034-5687(83)90101-9

20. Tomalak W, Pogorzelski A, Prusak J. Normal Values for Maximal Static Inspiratory and Expiratory Pressures in Healthy Children. Pediatr Pulmonol. 2002;34(1):42-6. DOI: http://dx.doi.org/10.1002/ppul.10130

21. Coelho CC, Aquino ES, Lara KL, Peres TM, Barja PR, Lima EM. Repercussões da insuficiência renal crônica na capacidade de exercício, estado nutricional, função pulmonar e musculatura respiratória de crianças e adolescentes. Rev Bras Fisioter. 2008;12(1):1-6. DOI: http://dx.doi.org/10.1590/S141335552008000100002

22. Oliveira EA, Fernandes FE, Torquato JA. Verificação do padrão respiratório e força muscular respiratória em pacientes pediátricos com neoplasias encefálicas. Pediatria. 2009;31(3):143-51.

23. Black LF, Hyatt RE. Maximal respiratory pressures: normal values and relationship to age and sex. Am Rev Respir Dis. 1969;99(5):696-702. DOI: http://dx.doi.org/10.1164/arrd.1969.99.5.696

24. Schmidt R, Donato CRF, Valle PHC, Costa D. Avaliação da força muscular respiratória em crianças e adolescentes. Praxis - Rev Fisioter Univers Cruz Alta. 1999;1(1):41-54.

25. Barreto LM. Comparação dos valores medidos e preditos de pressões respiratórias máximas em escolares saudáveis: criação de uma nova equação de referência preditiva de força muscular respiratória Tese (Mestrado) - Universidade Federal de Minas Gerais Belo Horizonte: 2012. 
26. Heinzmann-Filho JP, Vidal PCV, Jones MH, Donadio MVF. Normal values for respiratory muscle strength in healthy preschoolers and school children. Respir Med. 2012;106(12):1639-46. DOI: http://dx.doi. org/10.1016/j.rmed.2012.08.015

27. Nascimento RA, Campos TF, Melo JBC, Borja RO, Freitas DA, Mendonça KMPP. Valores encontrados e preditos para as pressões respiratórias máximas de crianças brasileiras. J Hum Growth Dev. 2012;22(2):166-172. DOI:http://dx.doi.org/10.7322/jhgd.44946

28. Camelo JS, Terra FILHO J, Manço JC. Pressões respiratórias máximas em adultos normais. J Pneumol.1985;11(4):181-4.

29. Petrini MF, Haynes D. In search of maximum inspiratory and expiratory pressure reference equations. Respir Care. 2009;54(10):1304-5.

30. Gomes ELFD, Peixoto-Souza FS, Carvalho EFT, Nascimento ESP, Sampaio LMM, Eloi JS, et al. Maximum Respiratory Pressures: Values Found and Predicted in Children. J Lung Pulm Respir Res. 2014;1(3):14. DOI: http://dx.doi.org/ 10.15406/jlprr.2014.01.00014

31. Borja RO, Campos TF, Freitas DA, Macêdo TMF, Mendonça WCM, Mendonça KMPP. Valores preditos para as pressões respiratórias máximas em crianças. Cons Saúde. 2015;14(2):187-94. DOI: http://dx.doi. org/10.5585/ConsSaude.v14n2.5109

32. American Thoracic Society. ATS/ Lung function testing: selection of reference values and interpretative strategies. Am J Respir Crit Care Med. 1991;144(5):1202-18. DOI: http://dx.doi. http://dx.doi.org/10.1164/ ajrccm/144.5.1202

This article is distributed under the terms of the Creative Commons Attribution 4.0 International License (http://creativecommons.org/licenses/by/4.0/), which permits unrestricted use, distribution, and reproduction in any medium, provided you give appropriate credit to the original author(s) and the source, provide a link to the Creative Commons license, and indicate if changes were made. The Creative Commons Public Domain Dedication waiver (http://creativecommons.org/publicdomain/zero/1.0/) applies to the data made available in this article, unless otherwise stated.

\section{Resumo:}

Introdução: Apesar da reconhecida importância da análise das pressões respiratórias máximas (PRM) em pediatria, tanto no seguimento de enfermidades que afetam a função dos músculos respiratórios, quanto da adequação do crescimento e desenvolvimento infantil, existe ampla variabilidade e regionalização quantos aos valores e equações de referência.

Objetivo: Descrever os valores de referência e equações preditivas das pressões respiratórias máximas para crianças brasileiras.

Método: Revisão de literatura realizada nas bases de dados LILACS, MEDLINE e Science Direct, utilizando os descritores estabelecidos pelo DeCS da Biblioteca Virtual em Saúde: valores de referência, criança, força muscular respiratória, equações preditivas, e seus sinônimos em inglês.

Resultados: Encontrou-se seis ensaios clínicos, com valores de referência para a população pediátrica, realizados em diferentes regiões brasileiras. Observou-se relação entre os valores das PRM e fatores como idade, estatura e massa corporal. Porém, houve relevante diferença entre os dados nos estados brasileiros e divergência entre os valores preditos.

Conclusões: Há consenso ao relacionar as pressões respiratórias máximas e fatores antropométricos, bem como uma influência regional. Os valores preditos e as equações de referência foram divergentes entre os trabalhos encontrados.

Palavras-chave: valores de referência, criança, força muscular respiratória, equações preditivas. 